(3)

Volume 25, 2022

\title{
INFORMING SCIENCE AND INTERNATIONAL RELATIONS: TRANSDISCIPLINARITY OF THE CONCEPTS CivilizATION, IDEOLOGY, AND GEOPOLITICS
}

\author{
Gurakuç Kuçi*
}

State University of Tetova in Northern

gurakuqkuqi@gmail.com Macedonia.

\section{ABstraCT}

Aim/Purpose

The integration of knowledge through the transdisciplinary method with the three concepts civilization, ideology, and geopolitics (CIG) enables the analysis of international relations in a new perspective and the informing strategists of countries, organizations, analysts, clients, etc. These three concepts express the transdisciplinarity that offers a new theoretical explanation and the informing science approach.

Background

The integration of knowledge using the three concepts for the analysis of international relations has found adequate explanations from 1890 until the withdrawal of the United States from Afghanistan. Therefore, the CIG model theoretically and practically finds support for more than a century, as argued in the paper.

Methodology

The present paper uses a mixed theory based on transdisciplinary methodology and informing science. The literature was reviewed to find and build the theoretical basis and provide appropriate examples. The theory is also based on the model used by Francis Fukuyama in his books on building and dissolution of states (middle-range theory).

Contribution This paper enables the rethinking of the limitations of research on a theoretical and practical basis that is done in many scientific circles, not to eliminate others but to enrich science even more.

Findings

In the paper, the main findings are the following:

Integrating the three CIG concepts according to the transdisciplinary method offers a new perspective to explain international relations using the IS method;

Accepting Editor Eli Cohen | Received: October 10, 2021 | Revised: December 6, December 15, 2021 | Accepted: December 16, 2021.

Cite as: Kuçi, G. (2022). Informing science and international relations: Transdisciplinarity of the concepts civilization, ideology, and geopolitics. Informing Science: The International Journal of an Emerging Transdiscipline, 25, 65-87. https://doi.org/10.28945/4889

(CC BY-NC 4.0) This article is licensed to you under a Creative Commons Attribution-NonCommercial 4.0 International License. When you copy and redistribute this paper in full or in part, you need to provide proper attribution to it to ensure that others can later locate this work (and to ensure that others do not accuse you of plagiarism). You may (and we encourage you to) adapt, remix, transform, and build upon the material for any non-commercial purposes. This license does not permit you to use this material for commercial purposes. 
Recommendations for Practitioners

Recommendations for Researchers

Impact on Society

Future Research

Keywords
The integration of the three concepts is worthwhile after 1980, when the model of cabinet governments falls, Bismarck falls, and public opinion starts to emerge;

It was after 1980 that theories of civilization and geopolitics began to emerge along with ideologies to apply in practice;

These three concepts offer explanations based on a CIG zone and in the periphery of the CIG zone. In the CIG zone the security sphere is more stable and long-term, while in periphery the cooperation is temporary and not long termed;

The paper shows that the Cold War period is divided into two periods;

The paper also finds that CIG explains with examples the events that happened after the Cold War and until present days;

The paper also shows, based on the strategies of the superpowers, how they are extending their influence based on the CIG concepts.

The paper also shows new patterns of cooperation and clashes between the superpowers' security zones, which also provide an explanatory perspective for the USA withdrawal from Afghanistan. (We do not talk in the paper about the Afghanistan issue and USA withdrawal).

The attributes identified by the transdisciplinary implementation of the three concepts express the evolution and behaviour of major policies and, as such, constitute a scheme for practitioners to analyse international relations and build strategies on an integrative rather than an exclusionary basis.

Scientific attributes in the integration of knowledge give researchers a more open and comprehensive perspective to make more accurate and practical analyses of international relations. According to this model, other theories are enriched that use the transdisciplinary method, IS, and the CIG as a model for the integration of knowledge.

This type of model enables an accurate understanding of cooperation between companies, their representatives, and the creation of safer areas and plans. Through this model, society no longer belongs to the abstract but is part of the analysis.

Researchers and practitioners of this CIG model can find answers such as "Why did the USA fail in Afghanistan and why was it successful in Kosovo?" as well as other questions about finding a solution for Iraq, cooperation with China, etc.

civilization, ideology, geopolitics, security zones, Cold War

[Editor's Note: The journal is pleased to print its first transdisciplinary paper on politics.]

\section{INTRODUCTION}

Today we cannot forget theories of international relations, but we cannot also isolate international relations (IR) to the theories of the 20th century. It is a curiosity in IR, that realism and liberalism, like theory and practice, were all used in the 19th century, but by cabinet governments (Cabinet governments are governments run by a group of ministers that were not elected by the people, or their prime minister or president is not elected by the people but by the king, emperor, prince, pope, etc.). 
Liberalism (Idealism) and Realism is the first great debate of disagreement between international relations scholars, (the story of international relations is conveniently told in the fourth "great debates") (Kurki \& Wight, 2013) and all other great debates are created based on critics to the first great debate. The first great debate in IR was a derivative of a long process of movements within countries based on liberalism movements. Liberalism was a movement aimed at promoting the rights of people and the economy. Liberalism abolished the British slave trade in 1833, and the Liberal plan was also successful in the Reform Bill of 1832, 1867, and 1884-85.

This movement was not having as much impact in other countries in the $19^{\text {th }}$ century for the reason that, as François Furet considers, after the French Bourgeois Revolution, the aristocracy had not disappeared, nor had the bourgeoisie dominated and that both of them had survived a plexus of literary but not political contradictions. Furet (1995) states that:

Nonetheless, throughout the nineteenth century, the aristocracy-yesterday's adversary—retained a vestigial splendor: it was Bismarck who unified Germany and Cavour who unified Italy. The monarchs and nobles of Europe largely maintained control of the course of events, while fearing their consequences. Even in France, where the old society had been legally destroyed from top to bottom and civil equality irreversibly instituted on 4 August 1789, the nobility made out very well after the fall of Napoleon. ... A degraded version of what classical political thought termed mixed government would take root all over nineteenth-century Europe, with shares going to the monarchy, to the aristocracy, and to democracy. In that bybrid political state, antibourgeois passion was bounded. (pp. 16-17)

The plexus between aristocracy and bourgeoisie begin to break after 1890 when Wilhelm II dismissed Bismarck from the position of Chancellor and did not renew the reinsurance agreement (Rich, 1992/2006, p. 252) between Germany, Russia, and Austria-Hungary. This rupture created new circumstances in Europe and new alliances between European nations. With the changing of alliances and with the new inventions in automobiles, energy, media, etc., the communication and distribution of information and ideology to mobilize masses were much easier. This opened a new terrain for organizing the masses - masses that wanted a voice. Gasset (1932) said: "the mass had decided to advance to the foreground of social life, to occupy the places, to use the instrument and to enjoy the pleasures hitherto reserved to the few" (pp. 16-17).

Under these circumstances was also created the first debate between realism and liberalism and in particular the theories of international relations with Kjellen, Mackinder, Toynbee, Ratzel, Mahan, etc. This inevitably brought about cooperation in terms beyond the interests of the elite people of government cabinets. This cooperation needs to create some methods of communication to produce successful strategies, and successful strategies need a transdisciplinarity approach. Therefore, with the transdisciplinary method, we have created a new approach for the understanding and explanation of IR and country strategies.

The transdisciplinary approach emphasizes language (not grammar) to understand the interrelationships between disciplines. Languages are more than just mediums of communication; they represent the relationship between people and their environment, and they are part of a larger discursive struggle over meaning and interpretation, an integral element of politics (Bleiker, 2001). Scientists are reticent to incorporate the subjectivity offered by ideology and civilization with geopolitics because many may think that civilization is representative of religion. Religious dominance in politics belongs to the Middle Ages, and scientists do not want a new Middle Ages. Today, civilization is not a religion; it has its genesis in religion, but today's civilization can be studied as a component of international relations: civilization represents values.

Civilization, ideology, and geopolitics (CIG) are concepts in IR like they are in some other fields; however, they can be also disciplines if we treat them like knowledge fields. However, in the transdisciplinary approach, they will work better as concepts and will be able to collaborate as concepts to 
explain and integrate ideas or themes. Thus, the CIG is not an abstract explanation, but a living hermeneutical dialectic.

To understand the language of disciplines, we need Informing Science (IS) because "Through the very use of the term 'know', we run into a problem - the distinction between what we 'know' to be true and what is 'actually' true" (Gill, 2016, p. 44) and in the Informing Science philosophy essence, we can transfer "knowledge from one field to another: breaking down disciplinary boundaries that hinder the flow of knowledge" (E. B. Cohen, 2009, p. 1). In this way, with transdisciplinary and IS, we can use the facts provided by international relations and create a model with the CIG to explain international relations.

This would then serve researchers and clients in the scientific and academic field, policy makers, multinational corporations (NCMs), and clients who have an interest in the development of a certain field.

Science, like peoples and states, prefers the status quo, and we must be conscious that when we begin to unpick rules we will be criticized, not for the science but because we are breaking the conformism boundaries. Shepherd (2014) said: "These boundaries that we establish between little pockets of knowledge in the academy are a fiction. Transdisciplinarity, to my mind, is about challenging the fiction of disciplines, about recognizing that knowledge is not something that can be carved up into neatly bounded parcels."

Considering climate change, the problems with drinking water, issues with energy, and pandemics, we can develop some transdisciplinary questions about international relations and other issues.

The examination of urgent questions shows the need for a transdisciplinary perspective of the CIG.

How does climate change affect geopolitics given the changing use of fossil resources? This question might, for instance, suggest that if the Sahara were filled with solar panels, it could produce enough solar energy for the entire world. It involves responses from more than two disciplines.

What are the reasons for the war and how can its consideration by the CIG bring about solutions for peace? Negotiations today involve various groups of experts who know the complexity of the situation.

International relations is not a discipline that can be studied with some concepts independently in a complex world, and much less in a globalized world. The purpose of this paper is not to abandon IR theories, but to break the fictional boundaries that separate IR from other areas of study, but also within itself IR.

In this paper the analysis includes only the period after World War II to the present.

\section{THEORIZATION}

The theoretical level will be according to what Fukuyama (2011) gives as a good model for the study of theories: "a middle-range theory that avoids the pitfalls both of excessive abstraction (the vice of economists) and excessive particularism (the problem of many historians and anthropologists)" (p. 24).

\section{THEORY OF CIVILIZATIONS}

Durant (1935) says: "Civilization is a social order promoting cultural creation. Four elements constitute it: economic provision, political organization, moral traditions, and the pursuit of knowledge and the arts. It begins where chaos and insecurity end. For when fear is overcome, curiosity and constructiveness are free, and man passes by a natural impulse towards the understanding and embellishment of life" (p. 22). 
Quigley (1979) defines civilization as: "a producing society with an instrument of expansion" (p. 142).

Civilization is like a social order that promotes the cultural creation in the first level; in another level of development, it is an instrument of expansion; nevertheless, in the middle period among the two levels we have the development of nationalism. Nationalism creates or recreates cultures that divide themselves from early civilization. So, in this term, Huntington (1996) said that: "A civilization is the broadest cultural entity. Villages, regions, ethnic groups, nationalities, religious groups, all have distinct cultures at different levels of cultural heterogeneity" (p. 43). We define civilization in the sense of a universal worldview and underlying comprehensive system of values that comprises "culture" as a sub-category (Köchler, 2014, p. 23).

Toynbee was an anti-nationalist and a pro-civilization or pro-western-unity under the civilization. He considered that "the ideal of our modern Western Democracy has been to apply in practical politics the Christian intuition of the fraternity of all Mankind" (Toynbee, 1934, p. 9). In similar terms Woodrow Wilson was also for the advancement of democracy and the father of liberalism in IR,

However, we must return to Toynbee's anti-nationalism because he saw nationalism as a form of disintegration and loss of the Western power and was a supporter of the collaborations that can be seen today in the EU-USA and NATO. Toynbee (1934) required the creation of an intelligible field of study (p. 22).

Before Toynbee's intelligible field of study was Spengler, who in his book "The Decline of the West" explained with the morphology of history denies the connections that civilizations may have between the ages. Nonetheless, he said: "The Civilization is the inevitable destiny of the Culture, and in this principle, we obtain the viewpoint from which the deepest and gravest problems of historical morphology become capable of solution" (Spengler, 1926. p. 49).

Spengler maintains that civilizations belonging to their time explains the fact that civilizations evolve and have their ups and downs, but civilization is the destiny of related or twin cultures. Therefore, since civilizations evolve and cultures produce nationalism, which undermines unity in civilization, this strengthens Toynbee's argument why he was an antinationalist.

Huntington (1996) alleges several decades later that "local politics is the politics of ethnicity; global politics is the politics of civilizations. The rivalry of the superpowers is replaced by the clash of civilizations" (p. 28) and this means that the cultures of the same civilization share a destiny and are unified in what Huntington calls the "core state".

Davutoğlu (2014) said that "globalization mobilizes all societies across the world in a much more multidirectional way such that it renders one-dimensional accounts of civilizational difference insubstantial."

The mobilization of societies is done by countries that represent expansionist or protectionist interests. Expansionist countries are the super-powers, and defensive countries are those who need expansionist countries to protect their interests. Therefore, civilization is the first basis for the more stable expansion of countries, because, in countries where a civilization unites many cultures, cooperation becomes more stable as in the case of the West. However, to make this cooperation within civilization a reality requires a "core state" or civil-centrism (civil-centrism is a term used by us to mean the unification of cultures under a civilization).

This kind of extension can be understood according to Quigley (1979), who says: "The ability of a society to defend itself on the military level is dependent on its ability to provide domestic order on the political level, wealth on the economic level, companionship on the social level, understanding on the intellectual level, and psychic certainty on the religious level" (pp. 119-120). 
Quigley represents an understanding of what we can find in the West today and what China is aiming to do as a representative of the far-eastern, Russia of the Orthodox, and potentially Turkey of the Muslims.

However, superpowers do not want the disappearance of another superpower, but only to keep it under control. It is more than obvious how the USA or Franklin Roosevelt at that time made China the world policeman. However, the West did not even want to dismantle China when the protests happened in Tiananmen. Few in the West are aware that the West is responsible for aggravating turbulence among the more than two billion people living in Islamic and Chinese civilizations (Mahbubani, 1993).

So, civilization is an instrument for expansion in IR and helps superpower countries to extend their geopolitics and other countries to provide themselves interests and this creates an intelligible area for science and countries.

\section{IDEOLOGY}

Roucek (1944) says: "Every model of thought, every philosophical or cultural product, begins with a specific social group from which it originates and with which its existence is connected. These patterns of thinking are 'ideologies."

John Plamentaz (as cited in Sullivan, 1973) says that ideology is "a set of closely-related beliefs or ideas, or even attitudes, characteristic of a group or community."

Micheal Howard (1989) said, "This [ideology] implies something much broader, looser, and less codifiable: a value system, a 'mind-set' as the Americans might call it, a Weltanschanungas the Germans do call it, or, in the French expression ... a mentalite."

Alan Cassels (2002) said: "ideology and the ideological pattern of thought supply a medium through which foreign policy issues can be transmitted to and perceived by a mass audience" (p. 9).

Thought patterns are, therefore, philosophical or cultural products which begin within a specific group; the attitudes and characteristics of the community create a system of values. Let us say that Marxism was an ideology established in the West but adapted to a cycle of transformation of the Asian dictatorship and implemented in the East, in Russia.

Although ideologies are rooted in great ideas, in the end they are transformed and adapted to find a more realistic application.

Democratic peace theory - the claim that democracies rarely fight one another because they share common norms of live-and-let-live and domestic institutions that constrain the recourse to war-is probably the most powerful liberal contribution to the debate on the causes of war and peace (Rosato, 2003). This theory derives from Western liberalism and has been used effectively to explain the unity of democracies and especially of Western democracies. Russia is competing with Western liberal democracy with "sovereign democracy" (Krastev, 2006). China in another way is doing a socialist model which provides, "a new option for other countries and nations who want to speed up their development while preserving their independence" (Gracie, 2017), or how Brands (2018) call the China approach an "authoritarian capitalism."

Repucci and Slipowitz (2021) write: "Nearly $75 \%$ of the world's population lived in a country that faced deterioration last year. The ongoing decline has given rise to claims of democracy's inherent inferiority. Proponents of this idea include official Chinese and Russian commentators seeking to strengthen their international influence while escaping accountability for abuses, as well as antidemocratic actors within democratic states who see an opportunity to consolidate power. They are both cheering the breakdown of democracy and exacerbating it, pitting themselves against the brave groups and individuals who have set out to reverse the damage." In addition, the report states that 
democratic and authoritarian countries are in balance and that democracy has been besieged for 15 years.

It is a fact that China and Russia are tending to extend to the countries that have a shared civilization, and this approach we can compare with the kin-country-syndrome.

Kin-country syndrome is a concept first applied from H. D. S. Greenway (1992) from the point of view of the ethnic card, but it was Huntington (1996) who extended this concept in the sense of civilization. Kin-country-syndrome is "Groups or states belonging to one civilization that become involved in war with people from a different civilization naturally try to rally support from other members of their own civilization" (Huntington, 1996, p. 35).

In these terms, ideology is a concept that cooperates with civilization to create and explain the strategies of countries like the USA, China, Russia, Turkey, and other powers. Civilization and ideology in transdisciplinary terms offer an explanation for why Turkey declined in the index of democracy and why they have a new geopolitical mindset. However, before explaining this, it is necessary to talk about geopolitics and the collaboration of geopolitics with civilization and ideology.

\section{THEORY OF GEOPOLITICS}

The central axis of world politics in the future are likely to be, in Kishore Mahbubani's (1993) phrase, the conflict between "the West and the Rest" and the responses of non-Western civilizations to Western power and values. Because of the civilizations that Huntington (1996) foresaw, "The most prominent form of this cooperation is the Confucian-Islamic connection that has emerged to challenge Western interests, values, and power" (p. 45).

Therefore, in similar terms, Brzezinski (1993) has developed his theory of a "geopolitical whirlpool" which predicts a collision along almost the same lines as Huntington.

Goldstein and Pevenhouse (2014) say: "The use of geography as an element of power is called geopolitics. It is often tied to the logistical requirements of military forces. In geopolitics, as in real estate, the three most important considerations are location, location, location. States increase their power to the extent they can use geography to enhance their military capabilities, such as by securing allies and bases close to a rival power or along strategic trade routes, or by controlling key natural resources" (p. 49).

There are three levels of geopolitics: Land Level (Heartland), Coast/Edge Level (Rimland), and Air Level. These three theories were developed by Mackinder, Spielman and Renner and these three authors have given the map of the development of global geopolitics wherein more or less similar dimensions it develops today.

Mackinder, for the first time with the paper "The Geographical Pivot of History" (1904) and then with the book "Democratic Ideal and Reality" (1919), wrote about the geographical importance of the land which he called Heartland. Spykman's theory (1944) stresses control of the sea and includes the nations that have access to the sea, the Rimland. Meanwhile, Renner (1942) constructed the theory of air, after the military revolution with the new dimension of forces which were established by the creation of the airplane.

Table 1 illustrates the geopolitical significance of the three theories that define the geopolitical field. It includes the geopolitical vision of three writers: Mackinder, Spykman, and Renner. These authors are the most important because they constitute the theory for the Heartland, Rimland, and air, and for this reason, in the table, we have summarized their vision. You can read their vision on the table in columns, and in rows to compare. This geopolitical vision that we summarized in the table also helps us to have a vision for extending civilization and ideologies. Without this table, we cannot create the vision for the CIG model to explain international relations because with this table, we have also an idea of where are the important civilization, ideologies, and the clash between them. 
Table 1: Geopolitical Extent based on Mackinder, Spykman, and Renner authors

\begin{tabular}{|c|c|c|c|}
\hline \multirow[b]{2}{*}{$\begin{array}{l}\text { Authors of } \\
\text { geopolitics }\end{array}$} & \multicolumn{3}{|c|}{$\begin{array}{l}\text { The geopolitical importance of territory according to three important au- } \\
\text { thors }\end{array}$} \\
\hline & Mackinder (Heartland) & $\begin{array}{l}\text { Spykman (sea/Rim- } \\
\text { land) }\end{array}$ & Renner (air) \\
\hline \multirow{4}{*}{$\begin{array}{l}\text { The geo- } \\
\text { political } \\
\text { extent } \\
\text { based on } \\
\text { the au- } \\
\text { thor's } \\
\text { strategy }\end{array}$} & Volga River in Russia & European coast & $\begin{array}{l}\text { Eurasia involving Russia, } \\
\text { Siberia, Turkmenistan, } \\
\text { and Western China }\end{array}$ \\
\hline & Yangtze River in China & $\begin{array}{l}\text { The Middle East with } \\
\text { Arabian droughts }\end{array}$ & \\
\hline & $\begin{array}{l}\text { Himalayan Mountains in } \\
\text { Nepal }\end{array}$ & The land of Asian rains & \\
\hline & Arctic Ocean & & \\
\hline
\end{tabular}

\section{But how did Brzezinski and Cohen, post-Cold War geopolitics theorists, perceive geopolitical confrontation?}

Affirming the lines of separation according to Huntington, but calling them a "geopolitical whirlpool," Brzezinski (1993) on the issue of Russia, the Middle East, Europe, and the Balkans said:

The geographical perimeters of the whirlpool of violence can be drawn as an oblong on the map of Eurasia. It extends from east to west, from the Adriatic Sea next to the Balkans all the way to the broader of the Chinese Sinkiang province; from south to north it loops around the Persian Gulf, embracing parts of the Middle East, then Iran, Pakistan, and Afghanistan in the south, all of Central Asia along the RussianKazakh frontier to the north, and all the way along the Russian-Ukrainian border. The oblong thus contains portions of southeastern Europe, the Middle East, and the Persian Gulf region, in addition to the southern sections of the former Soviet Union (pp. 163-164).

For China, Brzezinski (1993), citing Chinese strategists, said the first option is "confronting the trilateral coalition of America and Europe and Japan, the most effective geopolitical counter might well be to try to fashion a triple alliance of its own, linking China with Iran in the Persian Gulf-Middle East region and with Russia in the area of the former Soviet Union. Such an antiestablishmentarian coalition could be a potent magnet for other states dissatisfied with the status" (p. 198).

But even short of assuming such a historically dramatic role, China has a second option. It could pose a serious challenge to regional stability by seeking to assert itself as the principal Far Eastern power (Brzezinski, 1993, p. 199).

S. B. Cohen (2015) explains the extent of the geopolitical sphere by "the Atlantic and Pacific economically advanced maritime realm; the Eurasian continental Russian heartland; and the mixed continental-maritime East Asia" (p. 41). A nation's claim to power rests on four pillars: (1) overwhelming military strength and the willingness to use it; (2) surplus economic energy to enable it to provide aid and invest in other states; (3) ideological leadership that serves as a model for other nations; and (4) a cohesive system of governance (p. 2).

It is in the interest of countries that are at risk of falling under the control of other countries to develop geopolitical strategies; then civilization, ideology, and geopolitics as three concepts enable them to create a clearer strategy of cooperation and clash. Each of the three concepts has its scope; however, with the transdisciplinary method they offer the possibility of creating a state strategy or understanding the action, success, and failure of states in IR. 


\section{SECURITY SPHERES}

CIG by a country does not always apply in parallel (parallel means that CIG as a strategy or explanation of IR does not coexist each time as described to formula below and Figure 1). The great powers must expand their ideology and geopolitics to the extent that they must expand their civilization. Through the same ideology, a superpower is allowed to keep the regimes of foreign countries in power in most cases. However, in many cases, superpowers must set aside not only civilization, but also ideology (their values) and focus only on geopolitics. This is because, with certain countries, the present geopolitical interest is far greater than the pressure on them for an ideological change.

However, relations that are based on only one of the three concepts and not on all three do not form stable coalitions and fall within the framework of torn alliances. Torn alliances represent states that are in the periphery of a CIG zone. Those states are important for a CIG zone and also a CIG zone is important for them. Since they do not have a common CIG with a certain area, they can easily change sides by cooperating with another CIG area, remaining uninvolved in a clash, or even after the end of a clash period sever cooperation with a CIG area. That turns them into temporary allies. The torn alliances resemble torn states which Huntington (1996) defined as the "bridge between two cultures" (p. 139).

To better explain this, Figure 1 and the formula are developed as follows:

C represents civilization, I ideology, and G geopolitics, while P stands for periphery. (Periphery for our paper is the perimeter outside of a CIG zone, meaning the external border of a secure CIG. Periphery is not a zone with a CIG but cooperates or is a satellite state of CIG and is important for the security of CIG zone, but also a CIG zone and cooperation with it is important for that periphery state. Periphery state does not mean that is on a border with the CIG zone but means that it is an important state for the geopolitics of CIG zone). GICC stands for Ideological Geopolitics and civilcentrism.

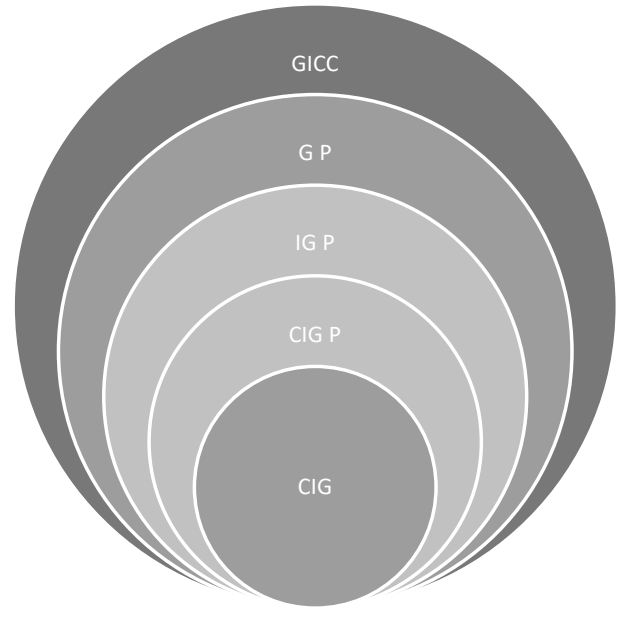

Figure 1: Civil-centrism formula

$$
\begin{aligned}
& \mathrm{C}+\mathrm{I}+\mathrm{G}=\mathrm{CIG} \text { where } \mathrm{C}<\mathrm{I}<\mathrm{G} \\
& \mathrm{CIG}<\mathrm{CIGP}<\mathrm{IGP}<\mathrm{GP} \\
& \mathrm{CIG}+\mathrm{P}+\mathrm{IGP}+\mathrm{GP}=\mathrm{GICC}
\end{aligned}
$$

This formula is based upon what has been explained thus far.

$\mathrm{C}+\mathrm{I}+\mathrm{G}=\mathrm{CIG}$ is a zone in which all three concepts are in a stable relationship; this is a secure zone. All countries in this zone have similar interests and cooperate without any unbridgeable problems. Countries in the CIG zone are much more secure than the countries in the Periphery, and countries in the CIG zone cooperate for a long time. For this reason, $\mathrm{CIG}$ is $\mathrm{C}<\mathrm{I}<\mathrm{G}$ but in this example, we have a country like Japan embraces values of the core state like the USA much more like a state in Periphery, e.g., Turkey.

In the second line of the formula (CIG $<\mathrm{CIGP}<\mathrm{IGP}<\mathrm{GP})$ CIG is less than CIGP as a zone, for the reason that CIG as a stable zone cooperates with countries that we call Periphery $(\mathrm{P})$ and consequently this is a much larger zone. However, CIGP is a zone when a CIG zone can extend civilization, ideology, and geopolitics relatively well making it a stable subzone. IGP represents the zone in which countries in a CIGP accept cooperation in terms of ideology and geopolitics, and GP represents cooperation in terms of geopolitics only. IGP is larger than CIGP and the GP is larger than 
IGP, because in both cases the CIG zone extends its interest and cooperates with countries where geopolitics is an interest to fight or to contain another zone. In these cases, the CIG zone accepts cooperation with countries in terms of ideology and geopolitics or only geopolitics. They do this because they know that it is impossible to extend their civilization or ideology and that if they exert pressure in this direction, they risk losing the alliance and thus security, or for other reasons, the CIG area has no interest in investing to expand its civilization or ideology to a country which does not express an interest in acquiring them of its own free will.

The third line of formula $(\mathrm{CIG}+\mathrm{P}+\mathrm{IGP}+\mathrm{GP}=\mathrm{GICC})$ is more complex but summarizes the CIG zone plus all the alternatives that the CIG zone extends or cooperates in Periphery with states that do not have stable cooperation, and here we include also torn alliances. CIG $+\mathrm{P}+\mathrm{IGP}+\mathrm{GP}$ are equal with Geopolitical Ideology and Civil-Centrism (GICC), because civil-centrism represents unification of cultures that are represented by a superpower of a CIG zone, and to create the Geopolitics of a civil-centrism we need an ideology that creates a political system. Then a political system based on ideology cooperates with a civilization which is not a system, but an umbrella for rough cultures to create unity. Ideology and civilization then create the strategy of extension of geopolitics in the CIG zone and in the Periphery with Geopolitical Ideology or solely Geopolitics. For this reason, we refer to it as "Geopolitical Ideology and Civil-Centrism". This formula is built on what has been explained so far. An example explanation of this formula during the Cold War would look like this: the USA CIG was Western Europe, Greece, Turkey, Japan, the IGP was South Korea and Vietnam, while the Middle East and the Horn of Africa was GP, as a whole, this constitutes the GICC.

\section{ANALYSIS ACCORDING TO THEORY AND FORMULA}

Assuming the above formula is correct, we can use it to divide the Cold War into two periods:

1. The first period is 1945-1950, in which the USA, to preserve and extend ideology, civilization, and geopolitics, takes measures against the ideological threat from Soviet Russia. Soviet Russia also applies similar measures within its sphere of influence. Both do this in the CIG security sphere.

2. The second period is 1951-1989, during which the clash is largely geopolitical and, to a lesser degree, ideological and far less for civilization.

Both periods have influences during the other period, but without losing the categorisation difference.

\section{STRIVING FOR THE PRESERVATION OF CIVILIZATION AND IDEOLOGY, THE PERIOD 1945-1950.}

After World War II, began the Cold War. While World War II was fought against Nazism, fascism, and militarism, which were racist ideologies, after World War II, clashes centered between the two camps, the Eastern or Communist and the West or Democratic. These two camps had neither racist nor exclusionary intentions but had intentions to extend their influence to as many states and territories as possible. The camps had not only ideological differences, but also civilizational and geopolitical differences, so both sides used all possible elements that served security and expansion.

Kissinger (1994) made the following statement:

The cultural gap between American and Soviet leaders contributed to the emerging Cold War. American negotiators acted as if the mere recitation of their legal and moral rights ought to produce the results they desired. However, Stalin needed far more persuasive reasons to change his course. When Truman spoke of the Golden Rule, his American audiences took bim literally and genuinely believed in a world governed by legal norms. To Stalin, Truman's words were meaningless, if not tricky, verbiage. The new international order he had in mind was Pan-Slavism reinforced by communist ideology. The Yugoslav dissident communist Milovan Djilas recounted a conversation in 
which Stalin had said: If the Slavs keep united and maintain solidarity, no one in the future will be able to move a finger. Not even a finger!' he [Stalin] repeated, emphasizing his thought by cleaving the air with his forefinger (p. 438).

So, we cannot understand the geopolitics of countries or create any IR strategy only with the geopolitics concept. We also need concepts of civilization and ideology for a better explanation or development of strategy. With CIG we can create an IR strategy or explain better the successful and unsuccessful actions of countries.

The attitudes of the leaders below show the division of the camps during the Cold War and their actions, which are designed in such a way that they lie within the civilization, ideology, and geopolitics of both camps.

In the statements by Stalin, Churchill, and Kennan, we understand the division that emerged after World War II.

On February 9, 1946, Stalin (1946), revealing his plans for the USSR, said that the war had not come accidentally. The Soviet system proved to be capable of existing and more stable than other systems.

On March 5, 1946, Churchill declared that "from Stettin in the Baltic to Trieste in the Adriatic, an iron curtain has descended across the Continent." In the same speech, he spoke about the issue of Turkey and Greece.

On February 22, 1946, before Churchill had drawn attention to the Cold War, George Kennan (1946) sent what became known as the "Long Telegram," and this telegram was taken seriously only after Churchill's speech. Kennan had repeatedly drawn the attention of the USA to abandon the ideas of cooperation with the USSR in favor of a sphere of influence policy in Europe (Miscamble, 2004). He also sought to strengthen Western institutions to make them invulnerable to the Soviet challenge pending the collapse of Soviet rule.

These declarations would be followed by measures with the proclamation of the Truman Doctrine, the Marshall Plan and the founding of NATO. During this period, Greece and Turkey were also taken into account in the Western security framework.

During this period, Moscow did just about the same in Eastern Europe. Moscow established the "Molotov Plan" in 1947 (Berger, 1948) to assist in the reconstruction of the USSR countries and satellite states.

In response to the Berlin crisis or Berlin blockade in 1948 that arose from an attempt of the USSR to force western allied powers to abandon post-World War II jurisdiction, the West made an even stronger three-conceptual (CIG) divide. However, while the West had a great deal of CIG coherence, the USSR on the other hand fell into the category of having a string CIG, but many of its areas like those in the Caucasus constituted a torn space. Turkey, although within the western security zone, was not a torn alliance since it was not occupied but was the security periphery to the west. Torn alliance means a country that is part of a camp in the Cold War as an occupied country like Polonia in USSR or any other country. A natural CIG has all countries that are part of a security zone and have civilization, ideology, and geopolitics approximately the same as a core state. Turkey does not have a natural CIG with western CIG, but as we have explained by the formula, Turkey in the Cold War had ideology and geopolitics approximately the same as western CIG.

\section{CLASHES IN THE PERIPHERY: 1950-1989}

Clashes in the periphery between both sides began after both camps had stabilized their power in the security zones covered by the CIG. Stabilisation in the western camp was founded with the creation of NATO in 1949 and the European Coal and Steel Community in 1951. We cannot say that the communist countries were truly a camp because the USSR, Yugoslavia, Albania, and China, in most things during the Cold War did not cooperate with each other. However, the 'Sino-Soviet Treaty of 
Friendship, Cooperation and Mutual Assistance" between China and the USSR in February 1950 and then in April, the end of the Communist Revolution in China was a forced signal for the USA to go beyond the CIG boundaries. The Warsaw Pact in 1955 was another signal that a new phase of clashes between camps had begun and clashes were on the periphery, not in the CIG security zone, but in the Periphery. The year 1955 is the year that made the real categorical leap from CIG to CIGP. A number of events made it possible to do so, as shown in Table 2.

Table 2: This table presents all the events that happened in 1955 that make this year an important year for transcending from one period to another period into the Cold War,

\begin{tabular}{|l|l|}
\hline The year 1955 & Events \\
\hline 29 January & Resolution for Formosa (Taiwan) \\
\hline 19 February & SEATO \\
\hline 24 February & Bagdad Pact \\
\hline March & The Soviets begin aid to Syria \\
\hline 5 April & Winston Churchill resigned from the British government. \\
\hline 18-24 April & African-Asian Conference / Non-Aligned Movement \\
\hline 5 May & The Allies end the military occupation of West Germany \\
\hline 9 May & West Germany joins NATO and begins rearmament \\
\hline 14 May & Warsaw Pact \\
\hline 15 May & Austria is declared a neutral country and the allies end the occupation \\
\hline & USSR arms sales to Egypt \\
\hline 18 July & Geneva Summit \\
\hline 1 November & Vietnam War \\
\hline 14 December & US and UK offer to Egypt to build the Aswan Dam \\
\hline
\end{tabular}

Since the events that took place after 1950 and 1955, we see that the clashes have gone to another level. Clashes are no longer just between the CIG camps, but also outside them. The West and the US in 1955 gave the Middle East and North Africa (MENA) the first concepts of cooperation within a civilization. Meanwhile, the Soviets and the Eastern countries were trying to make as many allies as possible within their periphery, either ideologically and geopolitically or only geopolitically.

The creation of the Baghdad Pact and Soviet aid to Syria and Egypt are two different forms of influence in the region: the first relating to cooperation issues and the second to exclusion (exclusion because the aid from USSR promoted nationalism and not cooperation as in an organization like the Baghdad Pact). The USA was not initially a member of the Baghdad Pact, but it was a direct result of the initiative taken by the United States Secretary of State, John Foster Dulles, after the latter's historic trip across eleven Middle Eastern capitals in May 1953 (Sanjian, 1997).

In the Arab and Islamic world, it was difficult to create unity, and the Baghdad Pact was not sufficient.

Unity within the Arab world in particular and the Islamic world as a whole extending to the Middle East and North Africa was impossible to be successful for two reasons: first, they were divided, weak, and without the necessary political culture to create high levels of unity like the West, and second, the influence of the communist camp of USSR and the democratic of the West was strong. The 
second reason further damaged MENA, which resulted in the weakening of any development progress. The Baghdad Pact left out influential states of strategic importance like Egypt. The latter was therefore influenced by both camps and cooperated with both camps, which is also why it is a member of non-aligned initiative countries.

In the Arab-Israeli conflict, the USA decided, on 31 December 1954, against selling arms to Egypt (Rubin, 1982), but the USSR had sold arms to Egypt through Czechoslovakia from 1955 to 1970. This cooperation began before the Geneva Summit on July 18, 1955, but the agreement and the sale took place two months after the Geneva Summit (Holbik \& Drachman, 1971).

The USA had tried to undermine cooperation between Egypt and the USSR by supporting the construction of the Aswan Dam in Egypt near the border with Sudan, where Great Britain also participated. "One way of winning friendship, suggested World Bank President Eugene Black, was by providing American aid for building the Aswan Dam" (Rubin, 1982).

The Anglo-American strategy was to press forward on the financing of the Aswan Dam and on effecting an Egyptian-Israeli peace, believing that the former could be used as bait to gain the latter. In July 16, 1956, however, the Senate amended the annual appropriations bill to bar the use of Mutual Security Act money for Aswan. On June 30, time had already run out on the earlier offering.

Before the USA withdrew from Aswan dam financing, in June 1956, the USSR offered Nasser $\$ 1.12$ billion at 2 percent interest for the construction of the dam.

The USA withdrawal from dam financing gave Nasser more pretext to take steps closer to the Soviets by declaring Arab nationalism as independence from the West and calling for war against the enemies, who for them were the West and Israel.

Egyptian President, Gamal Abdel Nasser (1956) in a speech announced the nationalization of the Suez Canal on July 26, 1956, after the USA withdrew funding for the Aswan Dam said:

Citizens, this is a war we are now engaged in. It is a war against imperialism and the methods and tactics of imperialism, a war against Israel, the vanguard of imperialism.... Arab nationalism is advancing. Arab nationalism triumphs. Arab nationalism marches forward; he knows his way, he knows his strength. Arab nationalism knows who its enemies are and who its friends are.

Emile Durkheim (1915) said that: "A nationality is a group of human beings, who for ethical or perhaps merely for historical reasons desire to live under the same laws, and to form a single state; and it is now a recognized principle among civilized peoples that when this common desire has been persistently affirmed it commands respect and is indeed the only solid basis of a state" (p. 40).

Ernest Gellner (1983) said: "Nationalism is primarily a political principle, which holds that the political and national unit should be congruent" (p. 1).

In Anthony D Smith (2010) definition nationalism is: "an ideological movement for attaining and maintaining autonomy, unity and identity for a population which some of its members deem to constitute an actual or potential "nation"' (p. 9).

Nexhmedin Spahiu (2021) said: "the nation is a community of capable people of building a state. This means that the nation is the owner of the state".

According to the definitions of nationalism, it turns out that Nasser used nationalization for political purposes, but his call was wrong due to the fact that he approached the Arab civilization. Based on the above explanations on nationalism, then, the Arabs are not like the Sino civilization that lies within China, but the Arabs are scattered in several countries, and as such they have their own nationalism in the states where they live. The nation is the people and the people belong to a country, and in cases when the people do not belong to the nation within a state they are called a national minority. Therefore, Arabs can have unity in civilization but not in nationalism. So even Nasser's appeal to 
Arab nationalism was scientifically poorly formulated, because in fact his appeal was beyond Egyptian nationalism to Arab civilization. The clashes that happened in the Middle East and North Africa from both camps involve only the extension of geopolitics, as neither side during the Cold War made any attempt to expand its ideology. Even attempts to keep the Iranian monarchy close to democratic ideology and liberals affiliated with the USA and the West failed by the 1979 revolution that brought to power a theocratic government based on Islamic religious leadership.

Other examples of where the ideological and geopolitical goals of another civilization do not fit, and failures are common are the cases of the USA in Vietnam and the USSR in Afghanistan.

We will treat only the Vietnam case in the context of the explanation according to the formula and when the formula is not followed, how geopolitical strategy fails. Indochina (Vietnam, Laos, Cambodia) emerging from the colonialism of some European countries inherited feudalism where $90-98 \%$ of the land was owned by some European owners or companies (Frankema, 2010). The partition of Vietnam, which occurred after the Geneva Summit came after a time when China was a communist country and had a deal with the USSR. On the South Vietnam side, the USA had sponsored a Catholic leader, Ngo Ding Diem, in the country where over 80 percent of the population were Buddhist and who was much less popular than the leader of North Vietnam, Ho Chi Minh (Jones, 2001, p. 367). Moreover, the hatred of Diem's power was increased by the attempt to isolate the peasants from having any contact with the north (Catton, 1999) and the suppression of the 1963 Buddhist protests against the rule of a Catholic President (Roberts, 1965). North Vietnam was also aided by China (Central Intelligence Agency, 2001), with which it had three-conceptual closeness, and also by the USSR (Holbik \& Drachman, 1971; Prybyla, 1966).

However, given the battles that took place there and the lack of popular support for power in South Vietnam and its sponsor, we know what happened; a USA geopolitics that aimed to extend beyond the $G$ (pushing ideology in a place where it should not) failed. The same thing happened to the USSR in Afghanistan, because the classic military occupation of a country like the USA in South Vietnam and the USSR in Afghanistan, imposing on the government of the occupied country beyond their civilization, ideology, and geopolitics, is almost never successful. So, if the United States in southern Vietnam and the USSR in Afghanistan pursued geopolitics without imposing their civilization and ideology, then success would be far more probable.

\section{DÉTENTE}

The failure in Vietnam and the coming to power of Richard Nixon in the USA made Henry Kissinger, Secretary of State for Foreign Affairs, change policy from that of containment to that of openness to the USSR and China. By 1969, Mao Zedong in the People's Republic of China had declared the Cultural Revolution accomplished (Kaufman, 1998). This further forced the Nixon administration to openness but remain "committed to the treaties signed, to provide a shield if a nuclear power threatened the freedom of a nation, and to provide support where aggression occurs" (Green, 1971).

Kissinger pursued the Washington-Moscow-Beijing triangular policy (Jones, 2001, p. 405). Nixon and Kissinger were both striving to create a world based on the balance of forces. Nixon stated on January 3, (1972).

\section{We must remember the only time in the history of the world that we have had any extended period of peace is when there has been balance of power. It is when one nation becomes infinitely more pow- erful in relation to its potential competitor that the danger of war arises. So I believe in a world in which the United States is powerful. I think it will be a safer world and a better world if we have a strong, healthy United States, Europe, Soviet Union, China, Japan, each balancing the other, not playing one against the other, an even balance (Buchan, 1972).}

This approach of the Nixon administration was a return to our formula after the failure of the alignment contrary to the formula in Vietnam. 
Reagan's rise to power in the United States was intended to defeat Soviet Russia ideologically and geopolitically by advancing western civilization in some Central and Eastern European nations. The Reagan Doctrine, an advancement between the Truman Doctrine and the Nixon Doctrine was a battle between idealism and realpolitik.

On April 26, 1984, Reagan would become the third American president to visit China (History.com Editors, 2020). This enabled Reagan, in his strategy to defeat the USSR, to keep China out of this battle. Reagan brought so much trouble to the USSR that it is believed that the USA influenced Gorbachev to come to power in the USSR. Kengor (2006) says both Andropov and Cherenko wanted Gorbachev in power because they saw him as the only adequate leader who could stand up to Reagan (p. 219).

Kissinger (1994) said: "The two strategic decisions which contributed most to ending the Cold War were NATO's deployment of America intermediate-range missiles in Europe and the American commitment to the Strategic Defense Initiative (SDI)" (p. 775).

Strengthening the CIG of the USA and the West and keeping China out of communist cooperation with the USSR against the USA and the West, enabled the creation of conditions for the collapse of the USSR, realized by Reagan.

\section{Clashes After THe Cold WAR}

The Middle East and North Africa would be the first area to measure the world's cooperation capabilities beyond the terms of the Cold War. This was caused by the Gulf War, or the invasion of Kuwait by Iraq in 1991, which put the world to the test. Although it appeared at the beginning that the test of world unity against aggression might pass the test, after the Gulf War and the international intervention, things have not progressed towards peace. Huntington (1996) calls this war the second civilization war since the Soviet-Afghan war in 1979 (p. 256).

The failure to overthrow Saddam's government in 1991, as well as the changing attitudes of Arab and Muslim countries, caused the area to boil over from internal and external clashes, especially in the peace process with Israel.

Manifestations of zeal and widespread support for Saddam Hussein within the Palestinian community have been among the principal causes of the disruption of the peace movement in Israel. Iraqi missile attacks have also contributed to undermining the progress made in recent years in altering Israel's perception of the Palestinians (Peretz, 1991).

Therefore, this whole area, not having a CIG unity of its own, but opposing the CIG of foreigners, has never been able to capitalize on its interests, nor to make possible any cooperation with countries that had interests in this area, as in the examples of Japan, Singapore, etc.

In the Western Balkans, the swing states like Yugoslavia had begun a bloody destruction. It was the revival of pan-Slavic projects by the Serbian political elite led by Slobodan Milosevic that aimed to invade Yugoslavia and revive projects from the Balkan wars (1913-1914). Such an idea was also brought to the fore in 1992 during Milosevic's visit to Greece, which began on June 26 (Serbia Calls for Confederation with Greece, 1992). He had even gone further when he publicly proposed a confederation between Greece, Macedonia (North Macedonia), and Serbia (Serbia Calls for Confederation with Greece, 1992).

The USA Christmas Warning ("Crisis in the Balkans," 1999) against Serbia in the case of Kosovo warned that shortly there would be involvement and extension of USA interests in the Western Balkans. Huntington (1996) is unclear when it comes to Serb-Albanian confrontations (p. 130, 138, 261, 315). The war and conflict of Albanians and Serbs for over 100 years has been a battle for the territory. Serbia has colonized Albanian territory like Kosovo, Sandzak, Presevo Valley, etc., and carried 
out ethnic cleansing of Albanians, not because of religion, but ethnicity and interest in land acquisition. The same problem occurred during the 1998-99 war in Kosovo.

However, what can be deduced from the theory is that the USA and the West in the Western Balkans could not only extend their peripheral geopolitics but also their complete CIG.

\section{THE REVIVAL OF RUSSIA AND THE WOUNDS OF TURKEY IN THE AFTERMATH OF THE INVASION OF IRAQ.}

Following the terrorist attack on the Twin Towers in New York, the United States made a visible commitment against terrorism in the world, thereby attacking and invading Afghanistan. It would not take long and in 2004, it would do the same with Iraq. However, unlike the fact that in the first intervention there was widespread military and moral support in the world, in the second time the USA was almost the only one except Britain and Australia in support of it.

Robert Kagan, regarding the intervention in Iraq, said, "Americans, by contrast, think they are still living in history, and need to use traditional power-political means to deal with threats from Iraq, alQaida, North Korea, and other malignant forces" (as cited in Fukuyama, 2004, p. 117).

Kissinger (2002) considered that: “The issue is geopolitical in essence. Iraq's policy is very hostile to the United States. Iraq possesses chemical and biological weapons that it has used in the war against Iran and its people. It is working to create nuclear weapons. If these capacities remain intact, they can be used at certain times for terrorist acts or to fuel regional and international unrest" (p. 451).

Gause (2009) said, "The issue of weapons of mass destruction was not the only factor in the American decision to go to war. The belief that an Iraqi political system built on American demands would be a modelling and pro-Western democracy in the region, thus pushing for reforms in neighbouring countries that would then reduce the possibility of terrorist groups developing in those countries. ... Strategic benefits from the rise of American power in the world centre of oil production and in a region directly related to Arab-Israeli issues" (p. 273).

As the United States pursued its geopolitical goals, other interests and threats emerged. North Korea was testing nuclear weapons, China was experiencing an economic boom, and Russian President Putin on April 25, 2005, stated that "we should acknowledge that the collapse of the Soviet Union was a major geopolitical disaster of the century. As for the Russian nation, it became a genuine drama. Tens of millions of our co-citizens and compatriots found themselves outside Russian territory. Moreover, the epidemic of disintegration infected Russia itself" (Putin, 2005).

Turkey has also demonstrated a new geopolitical mindset since Erdogan took office.

Western Europeans consistently rejected Turkey in any integration, and Turkey was hurt by USA intervention in Iraq. In response, Madeleine Albright (2006) stated:

Turkey has come a long way; it would be a mistake now for us to push it in the other direction. The United States has its own obligations. The decision of the Bush administration to invade Iraq shocked the Turks.

[...] Looking ahead ten years, it seems likely that the dominant power in the Persian Gulf will be Iran, allied with the Shiite majority in Iraq. It would be hard to overstate the importance of Turkey at that point, as a member of NATO, a leader within the organization of Muslim states, a friend to Israel, and a potentially unifying force throughout Europe and the Near East (pp. 248-249).

Albright had also realised that the world could no longer be understood in pure terms, whether ideological, civilizational, or geopolitical. Albright (2006) added that:

We had better accept that the world is filled with political Muslims, political Christians, political Jews, and political people of every other faith. It is no crime to have a political agenda. It is a crime, however, to act on a violent and lawless one. That distinction must be clear. In fact, if Al Qaeda is to be defeated, it will be by 
a brand of political Islam that fights for economic opportunity, personal freedom, and peaceful relations within and among the peoples of the world (pp. 299-300).

The fact that the USA was being active in its expansion also created the reawakening of Russia, which was acting in response to Kosovo's independence, with the secession of South Ossetia and Abkhazia from Georgia and later Crimea from Ukraine, although in other circumstances Russia intervened in Syria in 2015 when the USA had also intervened to overthrow Assad.

\section{The powerful countries plus Turkey}

BREXIT has made the EU not as eager or persistent as it used to be as a separate power from the United States. However, Kissinger said for BREXIT: "that Brexit will be used in a creative way not to see how to minimize the damage but how to create a new role for Europe and America in the Atlantic partnership" (Clinch \& Kharpal, 2017).

So with BREXIT, we can talk again about a Western unity in the CIG. By staying within the CIG, this is enabling unity again as in the Cold War, especially as the Biden administration is working to contain China, keeping Russia under control (now that this paper is being published a clash is happening between the West and Russia over Ukraine), and potentially with a new collaboration with Turkey.

China is already developing a powerful strategy in civilisation, ideology, and geopolitics. With geopolitics it is being done through the Belt and Road Initiative (BRI) project. The BRI project was originally called the One Belt One Road-OBOR and is considered the Silk Road reference by the Han Dynasty (206 BCE - 220 CE) of China. Launched in 2013 by President Xi Jinping, the vast collection of development and investment initiatives would stretch from East Asia to Europe, significantly expanding China's economic and political influence (Chatzky, 2020). Of the 144 countries in the world member in this project, 42 countries are in Sub-Saharan Africa, 34 BRI countries are in Europe and Central Asia (including 18 countries of the European Union that are part of the BRI), 25 BRI countries are in East Asia and the Pacific, 17 BRI countries are in the Middle East and North Africa, 20 BRI countries are in Latin America and the Caribbean, and 6 countries are in South East Asia (Wang, 2021).

China is extending its civilization based on "Heritage Diplomacy" which is mainly used by China for Asian countries (Winter, 2016). Heritage diplomacy can be wielded in a top-down one-directional fashion that ignores or restricts mutual engagement (Clarke, 2018). In China today, the idea of the Silk Road is deeply linked to the spread of Buddhism (Winter, 2020).

From an ideological perspective, referring to a speech by Xi Jin Ping in October 2017, Hall Brands (2018) cited Xi that "China now represented a successful alternative to the combination of liberal democracy and free markets espoused by the reigning superpower, the United States. Because China had achieved great prosperity and power through its model of authoritarian capitalism, it offered a new option for other countries and nations who want to speed up their development while preserving their independence." Brands said that "Xi's address, then, was not simply a declaration of geopolitical ambition. It was a reminder that modern great-power competition revolves around clashes of ideologies and systems of government no less than around clashes of national interests."

Russia, for its part, pursues a pan-Slavic geopolitics and a model of the Soviet Union. Ideologically it has created what is called "sovereign democracy" and by this term defines the political life of a society where political powers, authorities, and their decisions are decided and controlled by a diverse Russian nation to achieve material prosperity, freedom, and justice by all citizens, social groups, and nationalities, by the people who formed it (Krastev, 2006).

Russia's ideology is aimed mostly at near abroad (near abroad are the post-Soviet states, also known as the former Soviet Union, the former Soviet Republics, and in Russia as the near abroad, are the 15 sovereign states that were union republics of the Soviet Union) to keep the West away. Also, accord- 
ing to the statements of the Russian Orthodox Church, Sergei Lavrov, and Vladimir Putin, they appeal against and call for resistance to internationalist liberalization (western countries) and protection of Orthodox civilization (Hoffmann, 2019).

As for Turkey, it is the epicenter of the transit of all civilisations. It also presents a high potential for economic growth.

The end of the Soviet Union allows Turkey to become the leader of a revived Turkic civilization involving seven countries from the borders of Greece to those of China (Azerbaijan, Kazakhstan, Kyrgyzstan, Turkmenistan, and Uzbekistan). Encouraged by the West, Turkey is making strenuous efforts to carve out this new identity for itself (Huntington, 1996, p. 42).

It is in the interest of both the USA and the West for Turkey to become a powerful country that will extend its influence in the Islamic and Turkmen peoples (The Turkmen people are a collection of ethnic groups of Central, East, North and West Asia as well as parts of Europe and North Africa, who speak Turkic languages.), and this is done in the form stated above. It is also a competitor at the doors of Russia and has the description as given by Albright (2006) cited above in the paper.

Turkey's CIG, though not as powerful as the USA, China, or Russia, is in the USA interest, as Turkey is not only a member of NATO, but is close to Israel and for the USA, it would be better that Turkey be the world leader of Islam rather than Iran. Turkey's favour is enhanced by the USA's close relationships to several Persian Gulf countries, which in turn enables the USA to establish good relations with the Islamic world of the Middle East and North Africa indirectly through Turkey and directly where is allied with several countries of the Persian Gulf and thus isolate opponents like Iran.

\section{CONCLUSIONS}

Civilization, ideology, and geopolitics are three concepts that, through the transdisciplinary method, create opportunities for integrated research between different concepts and disciplines for international relations to create more accurate knowledge, strategies, and analysis.

Civilization as value, ideology as political system, and geopolitics as security (political, economic, etc.) create an integrated and more detailed map, which increases accuracy (in international analysis and the creation of strategies by different entities) and practicality based on the transdisciplinary philosophy of Informing Science.

CIG as a theory of integration of concepts and CIG as a formula of theoretical and practical explanation offer the integration of the knowledge of those around us. The success and failure of a strategy and the accuracy or inaccuracy of analysis hang on the dependent variables, as their values are studied on the assumption or demand on which they depend.

Each of the CIG concepts being dependent variables are the effect of circumstances that produce results (results are produced by people, states, different attitudes on certain issues, etc.), so the study and creation of strategies should not avoid the elements that provide accuracy or success. This is made possible by the transdisciplinary method.

The CIG transdisciplinarity has yielded results since the 1980s because after this period the cabinet governments collapsed and gradually moved to another stage of IR. This kind of approach has created a group of countries which have had more and more common interests, not to create a balance of powers, but the supremacy of powers. As long as the balances are enabled by realpolitik, supremacy requires the use of all internal and external opportunities. This kind of use of all means for supremacy then selects the faster elements that can create more stable coalitions to create security. The quickest possibility is unity through civilization, the most enduring is when ideology joins civilization, and both of these create geopolitics of security. When the CIG creates stability within all three concepts, then the tendency for international domination begins in the name of values as a system, security, or both. 
From the end of the Second World War until the end of the Cold War, the camps that clashed with each other represented a CIG and a CIG + Periphery built based on the model given in the paper.

The nonalignment camp in the Cold War mainly represented states that had differences with both sides of the CIG as a whole or with any of the CIG concepts. As such, being powerless to establish a CIG of their own and being states without interest or with mutual interest to keep any of the sides of the clash camps, then, as a model, they have chosen nonalignment. India has not been part of any of the camps for the fact that it had nothing in common with the CIG with any of the camps. The construction of Yugoslavia was uncommon for the fact that the influence of both camps was $50 \%$ $50 \%$ derived from a Churchill-Stalin agreement and was a torn state. Egypt had nothing to do with the clash camps, it was a nonaligned country, and their leaders were trying to achieve benefits of both camps.

From the end of the Cold War to the present day, the transition from bipolarity (Cold War) to unipolarity (after the Cold War until perhaps 2010) and now to multipolarity (2010- ...), CIG is found not only in the West with the United States of America as a core state or civil-centrism country and the Slav-Orthodox world, led by Russia, but also in other regions such as the far east with China, the Islamic world with tendencies for an Islamic core state from Turkey and Iran, but without intentions to become 'superpowers' in the traditional sense and representative states of a CIG zone, there are also countries like Japan, Indonesia, India, etc. Not all Islamic countries have the same civilization even when they have the same religion; Turkey and Indonesia are not the same because even though they are both Islamic, basically the civilizational values from history are different. Turkey is closer to MENA because of the past from the Ottoman Empire and the close geographical extent, and Indonesia is in another regional sphere if we think with regionalism theory.

The CIG after the Cold War has increasingly extended, especially from the West, to countries that have a different civilization, and they have made this union "united in diversity" (slogan of the EU) because the interest of this union has been much greater than the orthodox Bulgaria's cooperation with Russia under communism. However, such regions that lie on the borders of strong CIG show tendencies of alienation towards a strong CIG. This happens for two reasons: first that a CIG uses its authority towards enlargement, and second, that countries bordering on the CIG that are powerful and have a mix of cultures (not civilizations) and aim for the best for themselves. No country wants to be part of a Russian CIG under a system like communism, which has brought dictatorship and hunger to the people.

CIG from 1980 to the present days offers an analytical perspective on the possibilities of future clashes, also, the stagnation of democracy according to the democracy index, the rise of autocracies and the clashes between the West, Turkey, China, Iran, North Korea and others. The CIG based on the measurement of power relations can provide analysis for the future of international relations.

This paper offers a perspective for further analysis and invites readers to answer the questions "Does the formula work in explaining the strategies of countries like India, Japan, Indonesia, South Africa, etc.?"

\section{REFERENCES}

Albright, M. (2006). The mighty and the almighty. Harper Perennial.

Atkinson, G. W. (1947). The Sino-Soviet Treaty of Friendship and Alliance. International Affairs, 23(3), 357-366. https://doi.org/10.2307/3017226

Berger, M. (1948). How the Molotov Plan works. The Antioch Review, 8(1), 17-25. https://doi.org/10.2307/4609251

Bleiker, R. (2001). Forget IR theory. In S. Chan, P. Mandaville, \& R. Bleiker (Eds.), The Zen of international relations (pp. 37-66). Palgrave Macmillan. https://doi.org/10.1057/9780230286429 3 
Informing Science and International Relations

Brands, H. (2018). Democracy vs authoritarianism: How ideology shapes great-power conflict. Survival. Global Politics and Strategy, 60(5), 61-114. https://doi.org/10.1080/00396338.2018.1518371

Brzezinski, Z. (1993). Out of control. Simon \& Schuster.

Buchan, A. (1972). A world restored? Foreign Affairs, 50(4), 644. https://doi.org/10.2307/20037938

Cassels, A. (2002). Ideology and international relations in the modern world. Routledge.

Catton, P. E. (1999). Counter-insurgency and nation building: The strategic Hamlet programme in South Vietnam, 1961-1963. The International History Review, 21(4), 918-940. http://www.jstor.org/stable/40109167

Central Intelligence Agency. (2001, September). Status of Soviet and Cbinese military aid to North Vietnam. https://cia.gov/readingroom/docs/DOC 0000652931.pdf

Chatzky, A. (2020, January 28). China's Massive Belt and Road Initiative. Council on Foreign Relations. https://www.cfr.org/backgrounder/chinas-massive-belt-and-road-initiative

Churchill, W. L. S. (1946, March 5). The sinews of peace ('Tron curtain speech'). International Churchill Society. https://winstonchurchill.org/resources/speeches/1946-1963-elder-statesman/the-sinews-of-peace/

Clarke, A. (2018, October 8). Heritage diplomacy. Australian Policy and History Network. https://aph.org.au/2018/10/heritage-diplomacy/

Clinch, M., \& Kharpal, A. (2017, January 20). Kissinger says a "creative" Brexit could link Europe back with America and redefine the West. CNBC. https://www.cnbc.com/2017/01/20/kissinger-says-a-creative-brexit-couldlink-europe-back-with-america-and-redefine-the-west.html

Cohen, E. B. (2009). A philosophy of informing science. Informing Science: The International Journal of an Emerging Transdiscipline, 12, 1-15. https://doi.org/10.28945/425

Cohen, S. B. (2015). Geopolitics: The geography of international relations (3rd ed.). Rowman \& Littlefield Publishers.

Crisis in the Balkans; Statements of United States' policy on Kosovo. (1999, April 18, Section 1, p. 12). The New York. Times. https://www.nytimes.com/1999/04/18/world/crisis-in-the-balkans-statements-of-unitedstates-policy-on-kosovo.html

Davutoglu, A. (2010). Strategic depth: Turkey's international position (M. Hoxha, Trans.). Logos-A: North Macedonia. (Original work published in 2001.)

Davutoğlu, A. (2014). The formative parameters of civilizations. In F. R. Dallmayr, A. M. Kayapinar, I. Yaylaci, M. A. Kayapınar, \& İ. Yaylacı (Eds.), Civilizations and world order (pp. 73-97). Lexington Books.

Durant, W. (1935). The conditions of civilization. In W. Durant, The story of civilization, Vol 1: Our oriental heritage (p. 22). Simon \& Schuster.

Durkheim, E. (1915). "Germany above all": German mentality and war. A. Colin.

Frankema, E. (2010). The colonial roots of land inequality: Geography, factor endowments, or institutions? The Economic History Review, 63(2), 418-451. http://www.jstor.org/stable/27771619

Fukuyama, F. (2004). State-building governance and world order in the 21st century. Cornell University Press.

Fukuyama, F. (2011). The origins of political order: From prebuman times to the French revolution. Farrar Straus Giroux.

Furet, F. (1995). The passing of an illusion. The University of Chicago Press.

Gasset, J. O. Y. (1932). The revolt of the masses. W. W. Norton \& Company, Inc.

Gause, F. G., III. (2009). The international relations of the Persian Gulf. Cambridge University Press.

Gellner, E. (1983). Nations and nationalism. Payot.

Gill, T. G. (2016). Informing science volume one: Concepts and systems. Informing Science.

Goldstein, J. S., \& Pevenhouse, J. C. (2014). International relations. (10th ed.). Pearson Longman.

Gracie, C. (2017, October 25). China's Xi Jinping opens 'New Era' for country and the world. BBC News. https://www.bbc.com/news/world-asia-china-41744675 
Green, M. (1971). The Nixon Doctrine: A progress report. US Government Printing Office. Publication number 8572. https://bit.ly/3CVDejr

Greenway, H. D. S. (1992, December 3). The ethnic card. The New York Times. https://www.nytimes.com/2006/05/09/opinion/09iht-edgreenway.html

History.com Editors. (2020, April 23). President Reagan visits China. History. https://www.history.com/this-dayin-history/reagan-visits-china

Hoffmann, S. P. (2019). Huntington, world order, and Russia. Christian Scholar's Reviem, 48(3), 289-302. https://christianscholars.com/huntington-world-order-and-russia/

Holbik, K., \& Drachman, E. (1971). Egypt as recipient of Soviet aid, 1955-1970. Zeitschrift Für Die Gesamte Staatswissenschaft / Journal of Institutional and Theoretical Economics, 127(1), 137-165. http://www.jstor.org/stable $/ 40749433$

Howard, M. (1989). Ideology and international relations. Review of International Studies, 15(1), 1-10. http://www.jstor.org/stable/20097162

Huntington, S. P. (1996). The clash of civilization and the remaking of world order. Simon \& Schuster.

Jones, H. (2001). Crucible of power: A bistory of US foreign relations since 1897. Rowman \& Littlefield.

Kaufman, V. S. (1998). A response to chaos: The United States, the great leap forward, and the cultural revolution, 1961-1968. The Journal of American-East Asian Relations, 7(1/2), 73-92. http://www.jstor.org/stable $/ 23613308$

Kengor, P. (2006). The crusader, Ronald Reagan and the fall of communism. Harper Collins Publishers.

Kennan, G. (1946, February 22.) George Kennan's Long Telegram'. Wilson Center: Digital Archive. http://digitalarchive.wilsoncenter.org/document/116178

Kissinger, H. (1994). Diplomacy. Simon \& Schuster.

Kissinger, H. (2002). Does America need a foreign policy? Toward a diplomacy for the 21st century. Simon and Schuster.

Köchler, H. (2014). Civilization as instrument of world order? The role of the civilizational paradigm in the absence of a balance of power. In F. R. Dallmayr, A. M. Kayapinar, I. Yaylaci, M. A. Kayapınar, \& İ. Yaylac1 (Eds.), Civilizations and world order (pp. 19-33). Lexington Books.

Krastev, I. (2006). "Sovereign democracy", Russian-style. Insight Turkey, 8(4), 113-117. http://www.jstor.org/stable/26328656

Kurki, M., \& Wight, C. (2013). International relations and social science. In T. Dunne, M. Kurki, \& S. Smith (Eds.), International relations theories (3rd ed., pp. 14-35). Oxford University Press.

Mackinder, H. J. (1904). The geographical pivot of history. The Geographical Journal, 170(4), 298-321. https://www.iwp.edu/wp-content/uploads/2019/05/20131016 MackinderTheGeographicalJournal.pdf

Mackinder, H. J. (1919). Democratic ideals and reality: A study in the politics of reconstruction. H. Holt.

Mahbubani, K. (1993). The dangers of decadence: What the rest can teach the west. Foreign Affairs, 72(4), 10. https://doi.org/10.2307/20045709

Miscamble, W. (2004). George Kennan, a life in the foreign service. American Diplomacy, 9(2). https://ciaotest.cc.columbia.edu/olj/ad/ad_v9 2/miw01.html

Nasser, G. A. (1956, July 26). Discours de Gamal Abdel Nasser (Alexandrie, 26 juillet 1956) [Speech by Gamal Abdel Nasser (Alexandria, 26 July 1956)]. Notes et études documentaires. Paris: La Documentation française. 2008-1956. https://www.cvce.eu/s/5s

Peretz, D. (1991). The impact of the Gulf War on Israeli and Palestinian political attitudes. Journal of Palestine Studies, 21(1), 17-35. https://doi.org/10.2307/2537363

Prybyla, J. S. (1966). Soviet and Chinese economic aid to North Vietnam. The China Quarterly, 27, 84-100. http://www.jstor.org/stable/651476 
Informing Science and International Relations

Putin, V. (2005, April 25). Annual address to the Federal Assembly of the Russian Federation. http://en.kremlin.ru/events/president/transcripts/22931

Quigley, C. (1979). The evolution of civilization. Liberty Press.

Repucci, S., \& Slipowitz, A. (2021). Democracy under siege. Freedom House. https://freedomhouse.org/report/freedom-world/2021/democracy-under-siege

Renner, G. T. (1942). Human geography in the air age (A text for high school students). Macmillan.

Rich, N. (1992/2006). Great power diplomacy: 1814-1914 (Zaloshnja, J. Trans.). Dialogue Institute \& Communication, Albania.

Roberts, A. (1965). Buddhism and politics in South Vietnam. The World Today, 21(6), 240-250. http://www.jstor.org/stable/40393739

Rosato, S. (2003). The flawed logic of democratic peace theory. American Political Science Review, 97(4), 585-602.

Roucek, J. S. (1944). A history of the concept of ideology. Journal of the History of Ideas, 5(4), 479-488. https://doi.org/10.2307/2707082

Rubin, B. (1982). America and the Egyptian revolution, 1950-1957. Political Science Quarterly, 97(1), 73-90. https://doi.org/10.2307/2149315

Sanjian, A. (1997). The formulation of the Baghdad Pact. Middle Eastern Studies, 33(2), 226-266. http://www.jstor.org/stable/4283868

Serbia calls for confederation with Greece. (1992, July 4). Reuters. Serbian-Hellenic Brotherhood. http://www.serbia-hellas.com/articles/confederation.html

Shepherd, L. J. (2014, September 8). Transdisciplinarity: The politics and practices of knowledge production. The Disorder of Things. https://thedisorderofthings.com/2012/11/23/transdisciplinarity-the-politics-and-practices-of-knowledge-production/

Smith, A. D. (2010) Nationalism: Theory, ideology, bistory (2nd ed.). Wiley-Blackwell.

Spahiu, N. (2021, November 6). Keqkuptimet dhe keqinterpretimet e konceptit të kombit në opinionin publik shqiptar [Misunderstandings and misinterpretations of the concept of nation in Albanian public opinion]. Tv Shenja. https://shenja.tv/keqkuptimet-dhe-keqinterpretimet-e-konceptit-te-kombit-ne-opinionin-publik-shqiptar$\underline{21}$

Spengler, O. (1926). The decline of the West. Volume one: Form and actuality. Alfred A. Knopf.

Spykman, N. J. (1944). The geography of the peace. Harcourt, Brace.

Stalin. (1946, February 9). Stalin election speech. Seventeen Moments in Soviet History. http://soviethistory.msu.edu/1947-2/cold-war/cold-war-texts/stalin-election-speech/

Sullivan, E. (1973). Review of ideology, by J. Plamenatz. Political Theory, 1(1), 109-111. http://www.jstor.org/stable/191085

Toynbee, A. J. (1934). A study of history (Vol. 1). Oxford University Press.

Wang, C. N. (2021, December). Countries of the Belt and Road Initiative (BRI). Green Finance \& Development Center. https://greenfdc.org/countries-of-the-belt-and-road-initiative-bri/?cookie-statechange $=1642619944414$

Winter, T. (2016). Heritage diplomacy along the One Belt One Road. International Institute for Asian Studies. https://www.iias.asia/the-newsletter/article/heritage-diplomacy-along-one-belt-one-road

Winter, T. (2020, February). Silk roads and cultural routes. E - Flux Architecture. https://www.e-flux.com/architecture/new-silk-roads/313107/silk-roads-and-cultural-routes/ 


\section{AUTHOR}

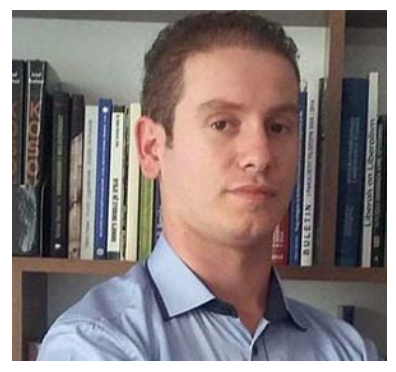

Gurakuç Kuçi is doctor in International Relations and History of Diplomacy from the State University of Tetova in Northern Macedonia. He is interested in exploring new explanation of international relations.

He is from Republic of Kosovo. 